\title{
Koulutuskritiikistä utopioihin
}

\author{
Giroux, Henry A. (2001) \\ Public Spaces, Private \\ Lives - Beyond the \\ Culture of Cynicism \\ With an Afterword by \\ Douglas Kellner \\ Lanham, Boulder, New \\ York and Oxford: \\ Rowman \& Littlefield \\ Publishers, 205 sivua
}

\section{On hämmentävää lukea} erittäin tuotteliaana kirjoittajana tunnetun Henry

Giroux'n toteamus kirjan alkupuheessa, että kirjoittaminen on hänelle aina vaikeaa. Giroux sanoo tarvinneensa tämän kirjan aikaansaamiseksi suuren tukijajoukon, johon kustantajan lisäksi kuuluu monia nimekkäitä kirjoittajia.

Hän kiittelee esipuheessaan myös lääkäriään, sillä toivuttuaan selkäleikkauksestaan hän pystyy taas istumaan ja kirjoittamaan ilman kipua. Giroux on ollut aktiivinen kirjoittaja jo parinkymmenen vuoden ajan. Ilmeisesti hänen koulutus- ja kulttuurikriittisillä kirjoillaan on riittänyt lukijakuntaa, vaikka monet hänen teoksistaan ovat tämän teoksen tavoin pikemminkin pitkiä kulttuuris-poliittisia dialogeja aikakauden muiden kirjoittajien kanssa kuin uutta teoriaa luovia tai teoreettisella argumentoinnillaan vakuuttavia tutkimuksia.

Giroux on tuotannossaan siirtynyt 1990-luvun alkupuolella kulttuurintutkimukselliseen lähestymistapaan. Hänen keskeisiä teemojaan ovat kirjan ylistävät jälkisanat kirjoittaneen Douglas Kellne- rin mukaan nuorison konstruoiminen ja representointi mediajulkisuudessa, Hollywood-filmien kriittinen analyysi sekä kulttuurin hahmottaminen pedagogisena toimintana. Giroux'n lähes vuosittain julkaistut kirjat ovat Public Spaces, Private Lives -teoksen tavoin esseekokoelmia, joiden teemat eivät nivoudu aina kovinkaan saumattomasti yhteen.

Kirjan viidestä pääluvusta ensimmäinen ja kaksi viimeistä käsittelevät kulttuurintutkimusta kriittisen pedagogiikan näkökulmasta sekä kulttuuria pedagogisen kamppailun kenttänä. Toisessa luvussa tarkastellaan konservatiivista politiikkaa ja diskursseja, jotka moittivat nuorisoa levottomuuden ja epäjärjestyksen lähteeksi ja "nollatoleranssia". Siltä pohjalta syntyneitä autoritaarisia toimintatapoja ja rangaistusmentaliteettia Giroux suomii kriittisesti. Kolmas luku käsittelee David Fincherin elokuvan Fight Club tuottamia maskuliinisuuden, väkivallan ja konsumerismin representaatioita.

\section{Teoksen syntyä on}

Giroux'n mukaan siivittänyt raivostuminen siitä, miten huonosti vähempiosaisia kansalaisia kohdellaan nykyisessä uusliberalismin ja globaalin kapitalismin läpitunkemassa markkinaorientoituneessa amerikkalaisessa yhteiskunnassa. Lähtökohtana ei ole abstrakti teoretisointi vaan kriisiytymässä oleva jokapäiväinen elämä, jota Giroux'n mukaan luonnehtii kyynisyyden, välinpitämättömyyden ja toi- vottomuuden kulttuuri.

Markkinamekanismit ja kuluttajuusajattelu ovat vallanneet kaikki elämänalueet, jopa koulut ja yliopistot.

\section{Giroux käy kirjassaan}

kulttuuris-poliittista keskustelua paitsi amerikkalaisten mediajulkisuuden henkilöiden, joista valtaosa on suomalaisille lukijoille tuntemattomia, myös erityisesti hänen näkemyksiään kritisoivien kasvatustieteilijöiden kanssa.

Giroux'n kirjoittamisen tapa on tässä kuten hänen muissakin teoksissaan lennokas ja tunnepitoisen kärjistävä eikä varmaankaan jätä kylmäksi ainakaan niitä, jotka joutuvat hänen kritiikkinsä kohteeksi. Tekstin vetoavuutta ja lennokkuutta lisäävät monet uudissanat. Giroux ryydittää puhettaan jatkuvasti muuttuvilla ilmauksilla. Sellaiset sanat kuin kieli, kansalaisuus, toivo ja utopia saavat useanlaisia määreitä. Esimerkiksi kieli voi olla paitsi kriittistä myös toivon kieltä tai mahdollisuuksien kieltä. Monien käsitteiden tarkkaa sisältöä on vaikea ymmärtää. Niiden äärellä myös tekstiä suomentava on usein ymmällään.

\section{Giroux peräänkuuluttaa} kansalaisuuskasvatusta ja heräämistä sosiaalisen oikeudenmukaisuuden tavoitteluun. Kollektiivista liikettä tarvitaan, sillä valtakulttuurissa on läpitunkevana kyynisyys, poliittisen mielikuvituksen puute sekä yhä laajeneva usko markkinoiden lakeihin, kilpailuhenkisyyteen ja kaiken mitattavuuteen taloudellisilla arvoilla. Giroux'n käsitteistös- 
sä usein toistuvia sanoja ovat toivo ja toivon luominen.

Tekstistä käy ilmi, että Giroux'ta arvostellaan yhtälailla konservatiivisen kuin vasemmistolaisen koulutuspolitiikan suunnalta. Jos Giroux'n edustamat ideat kulttuuri- ja koulutuspolitiikan uudistamiseksi ovat mm. koulutuksen tiedonsiirtämisfunktiota painottaville konservatiiveille kasvatustieteilijöille liian poliittisesti värittyneitä, ovat ne taas amerikkalaisille vasemmistokirjoittajille liian epämääräisiä ja epäteoreettisia keskittyessään kulttuurisen elämän ja politiikan suhteiden teoretisointiin ohittaen liiallisesti yhteiskunnan ja kulttuurin taloudellisen perustan. Giroux painottaa kulttuuria tilana, jossa käydään kamppailua materiaalisista resursseista, kommunikaatiosta, politiikasta ja vallasta.

Kulttuurin ja politiikan suhteiden tarkastelu on Giroux'n mukaan erittäin tärkeää teorian ja käytännön, vallan ja sosiaalisen muutoksen sekä pedagogiikan ja sosiaalisen toimijuuden välisten suhteiden ymmärtämiselle.

\section{Kirjan kiintoisinta antia} ovat sen kaksi viimeistä lukua. Luku neljä, jossa Giroux käy läpi ohjelmansa, on otsikoitu nimellä Masentuneiden pedagogiikka (Pedagogy of the Depressed). Aiemmissa teoksissa käyttämänsä termin toivon pedagogiikka hän on korvannut uudella nimellä, mutta muutoin hänen luonnostelemansa pedagogiikan ainekset vaikuttavat kovin entisenkaltaisilta. Giroux terottaa pedagogiikan yhteiskunnallista kontekstointia: pedagogiikka on tämän näkemyksen mu- kaan poliittinen ja eettinen käytäntö, jonka pohjana on toivon luominen. Pedagogiikka on sosiaalisesti konstruoitua ja keskeistä on analysoida miten tieto, arvot ja sosiaaliset suhteet rakentuvat ja miten ne kytkeytyvät valtaan. Kuten Giroux toistamiseen muistuttaa pedagogiikka ei ole koskaan viatonta, vaan aina poliittista ja tiettyihin arvojärjestelmiin sitoutunutta. Hän pyrkii murskaamaan voimallisin sanakääntein sen ylle kertynyttä poliittisen viattomuuden sädekehää.

\section{Muutoksen etu-} joukkoiksi Giroux haluaisi laittaa kouluttajat. Hänen mukaansa edistyksellisten kouluttajien täytyy pitää jatkuvasti mielessä, että koulutusta ja pedagogiikkaa muovaavat sen ulkopuoliset yhteiskunnalliset tekijät ja niihin myös koulutuksella vastataan. Oppilaat tulee saattaa tietoisiksi koulun ja laajemman yhteiskunnan keskinäisistä suhteista sekä siitä, miten vallankäyttöä tapahtuu oppimateriaalien, oppilaiden ja opettajien keskinäisissä suhteissa. Giroux peräänkuuluttaa tieteentekijöitä, kouluttajia ja työelämän organisoijia liittymään yhteen laajapohjaisiksi kansalaisliikkeiksi vastustamaan yliopistojen ja koulujen muuttumista markkinoiden valtaamaksi alueeksi. Yliopistojen ja koulujen tulisi kyetä toimimaan demokraattisen toiminnan alueina huolehtien ja ylläpitäen tasapainoa yhteisten arvojen ja kaupallisen kulttuurin sekä niiden edustamien ihmisten identiteetin rakentumista muovaavien arvomaailmojen välillä.

\section{Giroux'n esittämät} tavoitteet ovat vetoavia, jopa innostavia nykyisen teknis-rationaalisesti painottuneen koulutuskeskustelun keskellä. Leimallista Giroux'lle ja hänen edustamalleen kriittiselle pedagogiikalle on ohjelmallisuus. Mielenkiintoista olisi tietää myös, miten nämä toivon pedagogiikan ideat voitaisiin viedä koulutuskäytäntöjen tasolle. Giroux kylläkin tuottaa uusia käsitteitä, joiden avulla kuvata nykyisen kasvatusajattelun ja käytännön suunnittelun epäkohtia. Näiden käsitteiden hyödyntäminen jää kuitenkin puolitiehen: käsitteitä ei määritellä tarkasti eikä niitä käytetä kovinkaan yhtenäisesti. Ongelmana on, että Giroux'n käsiteapparaatti ei tarjoa käytännön toiminnan kehittämisestä kiinnostuneilla kovinkaan selkeätä psykologista, sosiologista tai kulttuurintutkimuksellista viitekehystä, jonka avulla omaa toimintaa voitaisiin tarkastella.

Giroux näkee ongelmaksi sen, että kasvatuksen tarkastelu on privatisoitunutta ja tyystin talouden ehdoilla toimivaa. Kasvatuksen keskeisiksi nähdyt tavoitteet liittyvät tuotannon ja työkyvyn lisäämiseen uusliberalistisessa talousjärjestelmässä. Giroux'n mukaan uusliberalismi kykenee tuottamaan vain dystopioita. Kyynisen yksilöllisyyden tilalle Giroux kaipaa utopioita oikeidenmukaisesta yhteiskuntajärjestyksestä. Hänen voimakkaimman kritiikinsä kohteena ovat keskustelijat, jotka korostavat nykyisen markkinatalouden ja demokratian tilan olevan välttämätön lähtökohta kasvatukselle. Giroux'n mukaan nyky-yhteiskunnan status quota ei voi ottaa kasvatuksen perustaksi, 
vaan on kyettävä tuottamaan yhteinen, jaettu visio nykyisen yksilöllistyneen poliittisen ajattelun tilalle. Giroux puolustaa väittämää, että kasvatuksellisessa toiminnassa on välttämättä läsnä utooppinen elementti.

\section{Giroux'lle utopioiden}

tulee herättää toivoa ja olla samalla realistisia. Utopioiden on tähdättävä nykyisyyden jälkeiseen maailmaan, joka ei ole vielä olemassa. Niissä on Giroux'n mukaan yhdistyttävä poliittinen toimijuus ja kriittinen kasvatus käytännön taisteluun. (Giroux'n ajattelu on usein militanttia, sillä hän lainaa käsitteitä sodankäynnistä.) Giroux'n utopia perustuu teesiin, että "politiikan ja moraalisen vastuun olemus on uskoa että ihmisillä on kykyä puuttua, vaikuttaa ja muovata rakenteita jotka heitä tuottavat" (s.123). Giroux'n oma termi onnistuneelle utopialle on kasvatukseen kytkeytyvä toivo (educated hope), joka yhdistää demokratian, poliittisen toimijuuden ja pedagogiikan diskurssit. Giroux'n ajatus, ettei ole olemassa utopioita ilman kasvatusta eikä kasvatusta ilman toivoa, on jatkoa hänen aiemmin kehittelemälleen toivon pedagogiikan teemalle.

\section{Giroux pyrkii tuomaan}

kasvatuksen näkökulman sekä kulttuurintutkimukseen että politiikkaan. Kasvatuksen toimijoiksi täytyy hänen mukaansa ymmärtää joukko kulttuurisia ja sosiaalisia instituutiota formaalisten oppimisinstituutioiden ohella, sillä taistelua kasvatuksesta käydään paitsi koulutuspolitiikassa myös kulttuuripolitiikan laajalla areenalla. Tämän takia hänen mukaansa poliittisessa toiminnassa on aina pedagoginen aspekti, ja pedagoginen toiminta sisältää aina poliittisen aspektin. Nykyiset poliittiset ja kulttuurintutkimukselliset analyysit eivät Giroux'n mukaan riittävällä tavalla kykene tavoittamaan pedagogisen ja poliittisen monimutkaista yhteenkietoutuneisuutta. Giroux'n ongelmana kuitenkin on, ettei hänen oma kulttuurikriittinen teoretisointinsa pääse hänen Ernst Blochilta vaikutteita saaneeseen tavoitteeseensa: hän ei tarjoa utooppista sosiaalista visiota, joka olisi samalla käytännöllinen.

\section{Giroux on kirjoittanut} kirjansa ennen syyskuun 11 . päivän terrori-iskua, joka herätti amerikkalaisen yhteiskunnan horroksestaan, mikäli se sellaiseen kyynisyyden ja epätoivon tilaan oli vaipunut, jota Giroux kirjassaan kuvaa. Se herätti amerikkalaiset turvallisuudentunteistaan ja nosti kollektiivisen, isänmaallisen hengen uuteen kukoistukseen. Terrorismin vastaisen sodan myötä alettiin turvallisuuden nimissä myös monenlaisia kansalaisvapauksia rajoittaa. Mielenkiintoista on, miten Giroux analysoi tulevissa puheenvuoroissaan amerikkalaisen yhteiskunnan kulttuurista ilmapiiriä, ja onko siellä enää edes entisessä määrin sijaa hänen ajamalleen sosiaalista oikeudenmukaisuutta edistävälle liikkeelle. Vai sidotaanko yliopistot ja koulutus, joita Giroux on peräänkuuluttanut uudistuksen etujoukoksi, yhä tiiviimmin kansakunnan yhtenäisyyden takaajiksi?

Katsomme, että puutteistaan huolimatta tällä Giroux'n teoksella - kuten hänen muullakin tuotannollaan - on annettavaa suomalaiselle kasvatustieteen kentälle. Giroux'n tarkastelemat teemat ovat kiinnostavia. Erityisesti koulutuksen ja kulttuurin kytkösten kriittinen analyysi on merkittävää, sillä Suomessakin näiden toiminta-areenoiden tarkastelut jäävät yleensä toisistaan erilleen. Samoin koulutuksen poliittisen viattomuuden sädekehän ravistelu on virkistävää antaen aineksia myös suomalaisen uusliberalismin valtaaman koulutuskentän analyysiin. Giroux'n kirja - vaikka keskittyykin amerikkalaisiin diskursseihin - tarjoaa paitsi yhteiskunta- ja koulutuskritiikkiä, luo myös katseen horisonttiin etsien muutoksen suuntaa utopiasta. Keskeistä on yhteisten arvojen löytäminen perustaksi oikeudenmukaisemmalle yhteiskunnalle, sekä koulujen ja yliopistojen säilyttäminen tiloina, joissa tätä yhteistä perustaa voidaan etsiä.

Tomi Kiilakoski\& Marjo Vuorikoski 